\title{
Basic soil properties as a factor controlling the occurrence and intensity of water repellency in rankers of the White Carpathians
}

\author{
Lucia Kořenková $\bowtie$, Martin Urík
}

Comenius University, Faculty of Natural Sciences, Institute of Laboratory Research on Geomaterials, Mlynská dolina, 84215 Bratislava, Slovak Republic, phone: +421-2-60296291, e-mail: korenkova@fns.uniba.sk

\begin{abstract}
Water repellency in soils is controlled by many different factors, basic physical and chemical properties might be considered the crucial ones. For the purpose of this study, 12 sites were selected and sampled $(0-20 \mathrm{~cm}$ depth $)$ in the White Carpathians. Repellency tests were conducted under laboratory conditions in triplicate using water drop penetration time (WDPT) test and the molarity of ethanol droplet (MED) test. Results of WDPT measurements showed that three samples were marked by slight to extreme water repellency. Regarding the relationship between WDPT/MED and tested soil properties, the highest value of correlation coefficient was calculated for soil organic carbon ( $r=0.706 ; p<0.05)$, suggesting there is a positive, statistically significant correlation between repellency severity and total carbon content. A negative relationship between repellency and soil reaction/silt/silt + clay contents of studied soils was found. Samples taken from the surface horizon of arable soils showed no repellency.
\end{abstract}

\section{KeY WORDS}

acid soil reaction, rankers, soil organic carbon, soil water repellency, White Carpathian Mts.

\section{INTRODUCTION}

Wettability of soils is a property that has been investigated frequently because of its influence on water movement, particularly on infiltration (Bachmann et al. 2003). Since soil is a porous medium, it is considered to have a high affinity for water. Water applied on soil surface is usually absorbed rapidly by soil due to adhesive forces between the water molecules and soil particles. However, not every soil shows this considerable attraction for water. There are soils showing various degrees of water repellency, which are difficult to wet (Das and
Das 1972). A soil is commonly classified as being water repellent if a drop of water placed on the soil does not spontaneously enter the soil. By this convention, a water repellent soil is one that has a water-solid contact angle equal to or greater than $90^{\circ}$. Soils classified as being wettable by this approach may have differing contact angels between 0 and $90^{\circ}$, which can affect soilwater relationships such as infiltration rates (Letey et al. 2000). Soil water repellency is a property of soils that can occur under natural conditions (Mataix-Solera et al. 2007), in different climate regimes, range of soil types and vegetation covers (Doerr et al. 2000). It has been 
reported from forest soils in Spain (Rodríguez-Alleres et al. 2012), Portugal (Doerr and Thomas 2000), Denmark (Wahl 2008), United States (Meeuwig 1971; Campbell et al. 1977; Lewis et al. 2006), Canada (Henderson and Golding 1983), Brazil (Johnson et al. 2005), Australia (Doerr et al. 2004), Japan (Kobayashi and Shimizu 2007) and elsewhere in the world. It is not a static soil property but is known to follow short-term or seasonal variations (Lichner et al. 2002). Factors such as surface chemistry, surface roughness and porosity may all influence perceived repellency, which also varies with soil wetness and temperature and possibly also atmospheric humidity (Hammond and Yuan 1969; King 1981). Water repellency is linked to soil properties such as acidity, texture and organic matter content and discontinuities of each contribute to a heterogeneous spatial distribution of soil erosion and hydrological response (Zavala et al. 2015). Therefore, the purpose of the work described here is to characterise the effect of some essential soil properties on water repellency of White Carpathians' rankers.

Although soil water repellency is widely thought to be influenced by soil $\mathrm{pH}$, there are only few studies that have systematically investigated the relationship between these variables. Diehl et al. (2010) present four mechanisms proposed for the $\mathrm{pH}-$ water repellency relationship: (I) in $\mathrm{pH}$ range between 4 and 7, which corresponds to $\mathrm{pH}$ of ranker soils, the changes in the surface charge of organic material caused by the protonation of carboxylic groups led to increased sessile drop-contact angles on a polymer surface with covalently attached carboxylic acid groups, (II) while organic matter structure remain compact in uncharged state, charged amphiphilic molecules' change in conformation loosen organic matter structural stability due to repulsion forces between their hydrophilic functional groups; this would involve a change in the degree of outward-exposed hydrophobic domains of macromolecules and formation of humic micelle-like structures on mineral surfaces, (III) leaching of fulvic acids, which preferentially at low $\mathrm{pH}$ leads to a low fulvic to humic acid ratio and a higher hydrophobic potential of these materials, and (IV) changes in bacterial and fungal communities. These conclusions are in good agreement with our results, which suggest negative correlation between $\mathrm{pH}$ values and soil water repellency. Unfortunately, this correlation was not statistically significant, most likely due to limited acidic soil $\mathrm{pH}$ range and studied number of collected soil samples.

\section{MAterial AND MEthOdS}

\section{Site description and soil sampling}

The concerned area is situated on the Slovak-Moravian borderland. The major part of the territory lies in a mid-temperate zone with short, moderately dry summers and mild winters. The forests are predominated by beech, oak, hornbeam and some conifers, such as Pinus sylvestris, P. nigra, Larix decidua, Picea excels. Grasslands are semi-dry and species-rich. Rankers account for less than $1 \%$ of the total area of the White Carpathians $\left(435 \mathrm{~km}^{2}\right)$ (Kuča et al. 1992). These are the soils with the low base saturation in the umbric A horizon, developing on the highly skeletic weathering material derived from consolidated silicate rocks. They dominate on the silica-cemented flysch sandstones. Increased occurrence of rankers that show evidence of cambic horizon formation and/or evidence of agricultural operations on acid rocks at lower altitudes has been observed in the south and middle part of the White Carpathians. (Javorinska and Lopenicka highlands).

For the purpose of this study, 12 samples were collected from the A horizon, in most places only weakly expressed. The sampling process was carried out in autumn 2012 following a warm-dry summer period since water repellency has been frequently observed in soils during prolonged droughts that may occur in the summer when soil water content tends to decrease and soil is more prone to repellency development (Dekker et al. 2001; Šimkovic et al. 2009). Forasmuch as rankers represent a rather rare soil type in this territory, a standard grid pattern for the sampling could not be employed. The position of each soil pit was located using GPS coordinates, which were then imported into a map of the area (Figure 1). The soils were classified according to Morphogenetic soil classification system of Slovakia (SPS 2000).

\section{Analyses of chemical and physical soil properties}

Samples were air-dried at room temperature and passed through a 2-mm sieve before analyses (Table 1). Soil organic carbon (SOC) content was determined using the rapid dichromate oxidation method (Walkley and Black 1934). The pipette method, based on the 'Stokes' sedimentation rates, was used to measure the percentage of sand (2-0.05), silt $(0.05-0.002)$ and clay $(<0.002 \mathrm{~mm})$ 




Figure 1. The map of the White Carpathians area (Slovakia) with soil pits localisation

Table 1. Some physical and chemical properties of the studied soils

\begin{tabular}{|c|c|c|c|c|c|c|c|c|c|}
\hline $\begin{array}{c}\text { Sample } \\
\text { No. }\end{array}$ & SOC (\%) & $\mathrm{pH} / \mathrm{H}_{2} \mathrm{O}$ & $\mathrm{pH} / \mathrm{KCl}$ & $\begin{array}{c}2-0.05 \mathrm{~mm} \\
(\%)\end{array}$ & $\begin{array}{c}0.05-0.002 \mathrm{~mm} \\
(\%)\end{array}$ & $\begin{array}{c}<0.002 \mathrm{~mm} \\
(\%)\end{array}$ & $\begin{array}{c}\text { Landuse } \\
(\%)\end{array}$ & $\begin{array}{c}\text { WDPT } \\
(\mathrm{s})\end{array}$ & $\begin{array}{c}\mathrm{MED} \\
(\%)\end{array}$ \\
\hline 1 & 4.58 & 3.48 & 3.09 & 33.0 & 56.0 & 11.0 & forest & 6 & 1 \\
\hline 2 & 3.12 & 4.48 & 3.67 & 74.5 & 14.9 & 10.6 & forest & 642 & 16 \\
\hline 3 & 4.53 & 5.15 & 4.43 & 60.7 & 30.7 & 8.6 & forest & 7 & 1 \\
\hline 4 & 2.81 & 7.22 & 6.60 & 36.4 & 40.2 & 23.4 & arable & 0 & 0 \\
\hline 5 & 4.63 & 4.47 & 3.67 & 61.8 & 27.7 & 10.5 & forest & 531 & 16 \\
\hline 6 & 15.03 & 3.64 & 2.99 & 44.7 & 33.2 & 22.1 & forest & 5346 & 19 \\
\hline 7 & 3.96 & 4.64 & 3.80 & 42.0 & 45.7 & 12.3 & forest & 11 & 1 \\
\hline 8 & 3.23 & 4.65 & 3.63 & 46.0 & 43.3 & 10.7 & forest & 2 & 0 \\
\hline 9 & 11.75 & 4.62 & 3.84 & 57.6 & 31.5 & 10.9 & forest & 993 & 18 \\
\hline 10 & 20.94 & 3.78 & 3.06 & 53.5 & 26.8 & 19.7 & forest & 1674 & 18 \\
\hline 11 & 12.87 & 4.50 & 3.74 & 52.1 & 39.7 & 8.2 & forest & 367 & 14 \\
\hline 12 & 3.50 & 7.37 & 6.62 & 51.6 & 30.4 & 18.0 & grassland & 1 & 0 \\
\hline
\end{tabular}

SOC - soil organic carbon, WDPT - water drop penetration time, MED - molarity of ethanol droplet. 
fractions in each soil sample. The soil textural class was determined using the USDA-FAO texture triangle (FAO 2006). Soil $\mathrm{pH}$ was measured potentiometrically in deionised water and in $1 \mathrm{M} \mathrm{KCl}$ with a soil:solution ratio of 1:2.5; the $\mathrm{CaCO}_{3}$ content was calculated from the weight of $\mathrm{CO}_{2}$ lost after treating a sample with excess hydrochloric acid.

\section{Soil water repellency}

The persistence of water repellency was determined using the widely used water drop penetration time (WDPT) test, which involved placing three drops of distilled water from a medicinal dropper onto the soil surface and recording the time required for complete droplet infiltration. For each sample, an average of three WDPT values was used. The volume of water in a droplet was $58 \pm 5 \mu \mathrm{l}$. A standard droplet release height of approximately $10 \mathrm{~mm}$ above the soil surface was used to minimise the cratering effect on the soil surface (Wylie et al. 2001). There were 5 repellency classes categorised according to WDPT (s): $<5$ - wettable, 5-60 slightly water repellent, 60-600 strongly water repellent, 600-3600 severely water repellent, $>3600$ extremely water repellent soil (Bisdom et al. 1993).

The severity of water repellency was assessed by the molarity of ethanol droplet (MED) test, which quantifies repellency as the lowest ethanol concentration permitting droplet penetration within $3 \mathrm{~s}$ (Doerr 1998), or alternatively, the $90^{\circ}$ liquid surface tension of the infiltrating droplet $(\gamma \mathrm{ND})$. Standardised solutions of ethanol in water were used, ranging from 0.172 to $3.396 \mathrm{~mol}$ $1^{-1}$. Drops were applied in order of increasing concentration until penetration occurred. Since sampling was conducted for eight weeks, a certain amount of variation in soil moisture content might have been expected. To ensure comparable conditions, WDPT test was performed on air-dried samples. The MED test was also performed on air-dried samples only in order to avoid dilution effect of the ethanol solution in the droplets caused by the water contained in field moist samples (Šimkovic et al. 2009). Both tests were performed under laboratory conditions.

\section{Statistical assessment}

Before regression analysis, the descriptive statistics (mean, median, standard deviation, mean deviation, coefficient of variation, range, minimum and maximum) were calculated for all variables. Pearson's coefficients of correlation, coefficients of determination and significance level were calculated for couples of measured soil properties using software Statistica ver. 7.0. Since several authors (Doerr et al. 2006; Bayer and Schaumann 2007) reported SOC content, soil textural composition and soil reaction as properties taking part in soil wettability, the linear regression analysis was performed using these particular variables as possible predictors of water repellency. Determined values of SOC content, soil reaction and content of individual textural fractions were used in simple linear regression analysis as independent variables $(\mathrm{X})$ in order to explain WDPT and MED values that were considered as dependent (Y). The least squares method was used for developing estimates of the model parameters.

\section{Results}

In the studied soils, there were nine showing different degrees of soil water repellency (three slightly, two strongly, three severely, one extremely water-repellent sample). Regarding WDPT, the upper measured time interval was $5346 \mathrm{~s}(1.5 \mathrm{~h})$. The highest ethanol concentration used was $19 \%$. Descriptive statistics for the whole set of samples are presented in Table 2. Regarding the SOC content, the measured values ranged from 2.81 to $20.94 \%$ SOC contents in wettable soils were the lowest. In accordance with findings of Harper et al. (2000), the degree of water repellency increased with increasing SOC content in rankers. SOC content of an extremely water-repellent sample was very high (15.03\%). Increasing the content of mineral fraction at the expense of organic fraction in soils may result in lower hydrophobicity (Szatyłowicz et al. 2006; Orzechowski et al. 2013). The calcareous leptosols have generally better physical and chemical properties than non-calcareous ones and are also less diverse. Nonetheless, all tested soils were non-calcium carbonated except for one wettable sample with $\mathrm{CaCO}_{3}$ content of $0.5 \%$. Since only this sample was taken from arable soil (Table 1), the presence of $\mathrm{CaCO}_{3}$ may be attributed to liming and/or fertiliser use when $\mathrm{CaCO}_{3}$ is added to soil to increase soil $\mathrm{pH}$. In the area, soil amendments are necessary since soil reaction (in $\mathrm{H}_{2} \mathrm{O}$ ) is very strongly acid (3.48) to slightly alkaline (7.37) with majority of 
Table 2. Descriptive statistics of measured soil properties concerning a whole set of 12 samples

\begin{tabular}{|l|r|r|r|r|r|r|r|r|}
\hline & \multicolumn{1}{|c|}{ mean } & median & \multicolumn{1}{c|}{ s.d. } & m.d. & c.v. & range & min. & max. \\
\hline SOC (\%) & 7.58 & 4.56 & 6.01 & 5.04 & 0.79 & 18.13 & 2.81 & 20.94 \\
\hline sand (\%) & 51.15 & 51.86 & 11.66 & 8.95 & 0.23 & 41.48 & 32.96 & 74.44 \\
\hline silt (\%) & 35.00 & 32.32 & 10.67 & 8.31 & 0.31 & 41.08 & 14.92 & 56.00 \\
\hline clay (\%) & 13.85 & 10.96 & 5.41 & 4.65 & 0.39 & 15.24 & 8.16 & 23.40 \\
\hline pH/H ${ }_{2} \mathrm{O}$ & 4.83 & 4.56 & 1.25 & 0.87 & 0.25 & 3.89 & 3.48 & 7.37 \\
\hline WDPT (\%) & 798.00 & 189.00 & 1524.00 & 936.30 & 1.91 & 5346.00 & 0.00 & 5346.00 \\
\hline MED (\%) & 8.67 & 7.50 & 8.63 & 8.16 & 0.99 & 19.00 & 0.00 & 19.00 \\
\hline
\end{tabular}

s.d. - standard deviation; m.d. - mean deviation; c.v. - coefficient of variation; SOC - soil organic carbon; WDPT - water drop penetration time; MED - molarity of ethanol droplet.

water-repellent samples with $\mathrm{pH}$ values between 3.48 and 4.6. $\mathrm{pH} / \mathrm{KCl}$ values are lower with a range of 2.99 to 6.62. According to the parent material, these soils can generally be sandy loam to clayey with different gravel content. The concerned area is formed by flysch sediments and the Klippen Belt, rankers occur principally on siliceous sandstones of the flysch area (Dlapa and Duriš 2006). The texture of the fine earth fraction here was classified as sandy loam (6 samples), loam (5) and silt loam (1). The presence of sandstones was evident, the soil samples contained $32.96-74.44 \%$ of sand. There were no wettable samples when the sand contribution was higher than $52 \%$. Content of particles $<0.002 \mathrm{~mm}$ ranged from 8.16 to $23.40 \%$. Soil water repellency is often associated with landuse and vegetation types. In the area of interest, all range of repellency classes (wettable to extremely water-repellent soils) have been found in soils under forests, while no repellency has been observed in soils under grass cover and in cultivated soil.

The strength of the relationship between WDPT/ MED and selected soil properties was low except for the SOC (Figure 2). The highest Pearson's coefficient (r) was calculated for SOC; the $r$ value for correlation between SOC and WDPT was 0.6326 , and 0.7063 for correlation between SOC and MED. Despite rather weak correlations between WDPT/MED and observed soil properties, the significance of some relationships evaluated by the $p$-level was relatively high, $<0.05$ for SOC (WDPT/MED) and silt content (MED). While repellency increased with increasing SOC content, a negative relationship was found between either severity or persistence of water repellency and soil reaction/ silt content. Surprisingly, a negative relationship was found also between persistence of water repellency and sand content, however, calculated $r$ value was very low $(r=-0.018)$. Nonetheless, any conclusion must be ap-
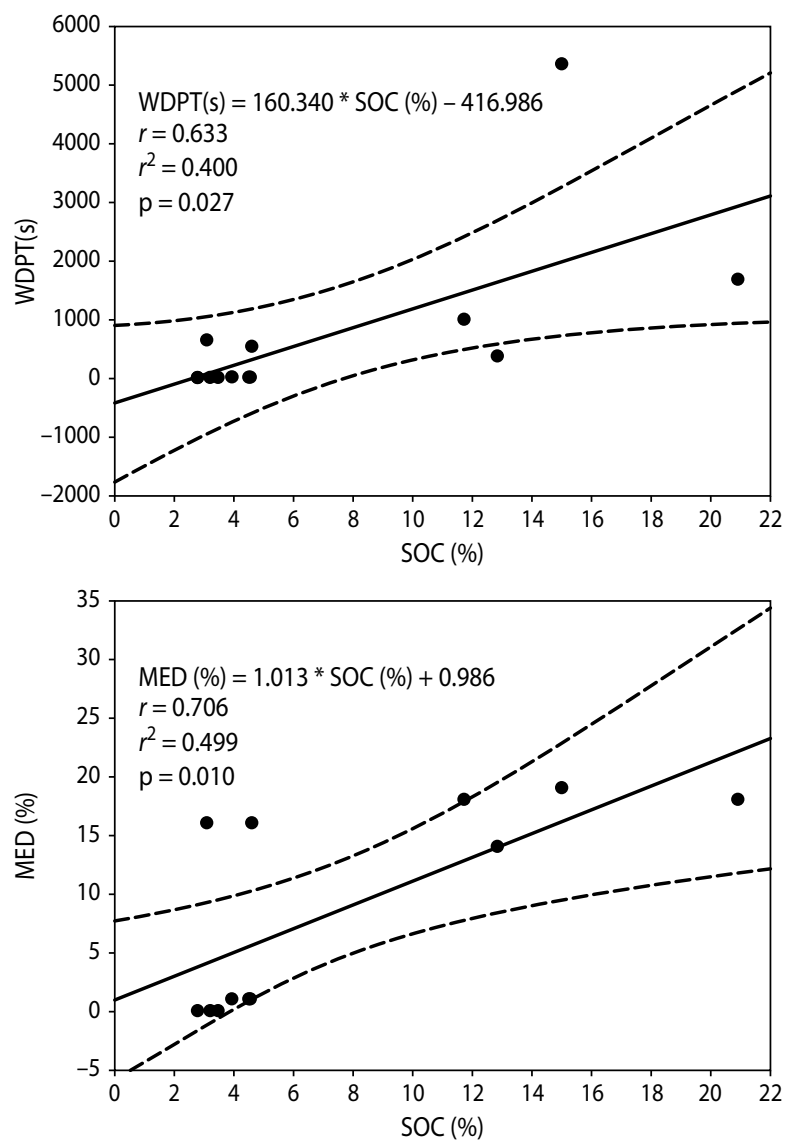

Figure 2. Relationship between WDPT / MED and SOC with calculated correlation coefficient, Pearson's coefficient and significance level of correlation $(\mathrm{N}=12)$

WDPT: water drop penetration time; MED: molarity of ethanol droplet; SOC: soil organic carbon. 
proached with caution as statistical analysis was based on 12 soil samples.

\section{Discussion}

Soil water repellency is being researched in many environments of the world and after decades of intense research, it has become obvious that it can be found at any ecosystem (Cerdà et al. 2015). Soil properties may determine the occurrence and intensity of this property. Organic matter and clay content together with the mineralogy of the clay fraction seem to be responsible for the different soil behaviour (MataixSolera et al. 2013). Having a large specific surface area and related absorption capacity, soil organic matter can modify surface properties of the mineral solid phase affecting hydrological characteristics through coatings on grains. Even a small increase in organic matter content can change soil hydrological properties from a completely wettable to a partially water-repellent state (Czachor et al. 2013). The involvement of fungal biomass in water repellency has long been investigated since it is also related to the soil organic matter content. Lozano et al. (2013) who studied a large number of chemical and biological factors under the influence of different plant species discovered that soil water repellency found under Pinus sp., a conifer abundant also in the White Carpathians region, appears to be the most influenced by fungi. Their results suggested lipid fraction as the principal factor. In fact, literature has emphasised the importance of lipid fractions released to soil by plants or microorganisms, such as fungi (Ma'shum et al. 1988; Hudson et al. 1994; Franco et al. 2000a) as well as the behaviour of specific characteristics of the organic matter, in general associated with moisture regimes. The latter mentioned was pointed out also by Šimkovic et al. (2009) who reported on water repellency of dystric Cambisols in mountainous region of the High Tatras. The water-repellent topsoil had properties similar to those of the soils examined in this study (strongly acidic (3.21-4.08) pH in the majority of samples, sandy loam texture and SOC content between 3 and 13\%). It was found that besides organic matter and field water contents, susceptibility of soil to become water repellent is significantly controlled also by soil reaction.
Furthermore, water repellency is most pronounced in coarse sands and sandy soils due to accumulation of hydrophobic compounds on soil particles or to physico-chemical changes in soil organic matter. As soils dry, hydrophobic compounds polymerise and repellency increases (Kostka et al. 2002). However, our results indicated a negative relationship between water repellency persistence and sand content in ranker soils.

Water repellency has been reported regularly from many soils around the world, including the arable ones (Franco et al. 2000b; Roper 2005; Feeney et al. 2006). Notwithstanding, there are reports that have shown that cultivation (Harper et al. 2000) and the use of fertilisers may affect soil wettability (Thorsen et al. 2010). The extended research conducted in White Carpathians. revealed that besides rankers, there were also the other soil types (including rendzinas, cambisols, luvisols) that showed no water repellency when cultivated and treated with fertilisers. The tested ranker soil used for agricultural purposes contained $0.5 \% \mathrm{CaCO}_{3}$ and a substantial portion of humified organic matter, had a neutral soil reaction and its textural composition was classified as loam, according to FAO. It is highly probable that these factors give a predisposition to this soil to show wettable character rather than water repellent. The properties of studied grassland soil were relatively similar to those of arable one; similar SOC content, loam texture, slightly alkaline reaction. We can, therefore, assume that this soil was, in fact, subjected to cultivation in the past.

Water repellency is a property that affects some natural soil functions and processes, such as infiltration, water retention, hydraulic conductivity, thermal conductivity and plant-water relationships. Due to shallow and skeletal soil profile, the filtering function of ranker soils is usually extremely low. Besides slope, water repellency is a factor that may decrease the filtering function of soil and thus, in case of arable soils, increase the possibility of nutrient losses and water pollution. The interaction of slope angle and length with water repellency has also an effect on the magnitude of erosion. Water repellency of the topsoil may further cause non-uniform wetting and fingered preferential flow (Dekker et al. 2001) that leads to uneven distribution of water in the crop root zone and accelerates the contaminant transport to ground water (Wang et al. 
2000); and an increased surface runoff resulting in soil erosion (Shakesby et al. 2000) and a nutrient washout (Lennartz et al. 1997) mainly during heavy rainstorms after prolonged dry periods.

\section{Conclusion}

The persistence of water repellency of A horizons of 12 ranker soils was estimated using WDPT test; 9 were found water repellent with time needed for water to infiltrate up to $5346 \mathrm{~s}$. Except for one sample with very low $\mathrm{CaCO}_{3}$ content $(0.5 \%)$, the other soils examined contained no $\mathrm{CaCO}_{3}$. While our results confirm generally accepted assumption that water repellency of topsoil material is mostly controlled by organic carbon contents, other quoted soil parameters, including texture and soil reaction showed only weak correlation between repellency and observed parameters. A negative relationship was found between persistence of repellency and $\mathrm{pH} / \mathrm{sand} / \mathrm{silt}$ content and between severity of repellency and $\mathrm{pH} /$ silt content of soils.

\section{ACKNOWLedgements}

This work was supported by VEGA contract No. 1/0203/14.

\section{References}

Bachmann J., Ellies A., Hartge K.H. 2003. Sessile drop contact angle method. In: Soil Water Repellency. Origin, assessment, occurrence, consequences, modeling, and amelioration (eds.: C.J. Ritsema, L.W. Dekker), Elsevier, The Netherlands, 57-65.

Bayer J., Schaumann G.E. 2007. Development of soil water repellency in course of isothermal drying and upon $\mathrm{pH}$ changes in two urban soils. Hydrological Processes, 21, 2266-2275.

Bisdom E.B.A., Dekker L.W., Schoute J.F.T. 1993. Water repellency of sieve fractions from sandy soils and relationships with organic material and soil structure. Geoderma, 56, 105-118.

Campbell R.E., Baker M.B. Jr., Ffolliott P.F., Larson F.R., Avery C.C. 1977. Wildfire effects on a ponder- osa pine ecosystem: an Arizona case study. USDA Forest Service Research Paper, RM-191, 1-12.

Cerdà A., Pelayo Ó.G., Orenes F.G., Jordán A., Pereira P., Novara A., Neris J. 2015. Long-term water repellency in organic olive orchards in the Cànyoles River watershed. The impact of land management. Geophysical Research Abstracts, 17, EGU2015-15079-1.

Czachor H., Hallett P., Lichner L., Jozefaciuk G. 2013. Pore shape and organic compounds drive major changes in the hydrological characteristics of agricultural soils. European Journal of Soil Science, 64, 334-344.

Das D.K., Das B. 1972. Characterization of water-repellency in Indian soils. Indian Journal of Agricultural Science, 42, 1099-1102.

Dekker L.W., Doerr S.H., Oostindie K., Ziogas A.K., Ritsema C.J. 2001. Water repellency and critical soil water content in a dune sand. Soil Science Society of America Journal, 65 (6), 1667-1674.

Diehl D., Bayer J.V., Woche S.K., Bryant R., Doerr S.H., Schaumann G.E. 2010. Reaction of soil water repellency to artificially induced changes in soil $\mathrm{pH}$. Geoderma, 158 (3/4), 375-384.

Dlapa P., Ďuriš M. 2006. Diverzita pôdneho krytu a jeho vlastností ako súčast' životného prostredia Bielych Karpát a Myjavskej pahorkatiny. Acta Environmentalica Universitatis Comenianae, 14 (2), 19-30.

Doerr S.H., 1998. On standardizing the water drop penetration time and the molarity of an ethanol droplet technique to classify soil hydrophobicity: a case study using medium textured soils. Earth Surface Processes and Landforms, 23 (7), 663-668.

Doerr S.H., Blake W.H., Shakesby R.A., Stagnitti F., Vuurens S.H., Humphreys G.S., Wallbrink P. 2004. Heating effects on water repellency in Australian eucalypt forest soils and their value in estimating wildfire soil temperatures. International Journal of Wildland Fire, 13 (2), 157-163.

Doerr S.H., Shakesby R.A., Walsh R.P.D. 2000. Soil water repellency: its causes, characteristics and hydro-geomorphological significance. Earth Science Reviews, 51, 33-65.

Doerr S.H., Shakesby R.A., Dekker L.W., Ritsema C.J. 2006. Occurrence, prediction and hydrological effects of water repellency amongst major soil and land-use types in a humid temperate climate. European Journal of Soil Science, 57, 741-754. 
Doerr S.H., Thomas A.D. 2000. The role of soil moisture in controlling water repellency: new evidence from forest soils in Portugal. Journal of Hydrology, 231-232, 134-147.

FAO 2006. Guidelines for soil description. $4^{\text {th }}$ edition. Rome, Italy: Food and Agriculture Organization of the United Nations.

Feeney D.S., Crawford J.W., Daniell T., Hallett P.D., Nunan N., Ritz K., Rivers M., Young I.M. 2006. Three-dimensional microorganization of the soilroot-microbe system. Microbial Ecology, 52, 151-158.

Franco C.M.M., Clarke P.J., Tate M.E., Oades J.M. 2000a. Studies on non-wetting sands: II. Hydrophobic properties and chemical characterization of natural water-repellent materials in Australian sands. Journal of Hydrology, 231/232, 47-58.

Franco C.M.M., Michelsen P.P., Oades J.M. 2000b. Amelioration of water repellency: application of slowrelease fertilisers to stimulate microbial breakdown of waxes. Journal of Hydrology, 231/232, 342-351.

Hammond L.C., Yuan T.L. 1969. Methods of measuring water repellency of soils. In: Proceedings of a symposium on water repellent soils (eds.: L.F. DeBano, J. Letey), May 6-10, 1968, Riverside, CA., 49-60.

Harper R.J., McKissock I., Gilkes R.J., Carter D.J., Blackwell P.S. 2000. A multivariate framework for interpreting the effects of soil properties, soil management and landuse on water repellency. Journal of Hydrology, 231/232, 371-383.

Henderson G.S., Golding D.L. 1983. The effect of slash burning on the water repellency of forest soils at Vancouver, British Columbia. Canadian Journal of Forestry Research, 13, 353-355.

Hudson R.A., Traina S.J., Shane W.W. 1994. Organic matter comparison of wettable and non-wettable soils from bentgrass sand greens. Soil Science Society of America Journal, 58, 361-367.

Johnson M.S., Lehmann J., Steenhuis T.S., de Oliveira L.V., Fernandes E.C.M. 2005. Spatial and temporal variability of soil water repellency of Amazonian pastures. Australian Journal of Soil Research, 43, 319-326.

King P.M. 1981. Comparison of methods for measuring severity of water repellence of sandy soils and assessment of some factors that affect its measure- ment. Australian Journal of Soil Research, 19, 275-285.

Kobayashi M., Shimizu T. 2007. Soil water repellency in a Japanese cypress plantation restricts increases in soil water storage during rainfall events. Hydrological Processes, 21 (17), 2356-2364.

Kostka S.J., Dekker L.W., Oostindie K., Ritsema C.J., Miller C.M., Karcher D.E. 2002. Advances in understanding and managing water repellent soils. In: Understanding and addressing conservation and recycled water irrigation. Conference proceedings, S.1., Irrigation Association/Omnipress, (cd-rom).

Kuča P., Májsky J., Kopeček F., Jongepierová I. 1992. Biele Karpaty. Vydavatel'stvo Ekológia. Bratislava.

Lennartz B., Louchart X., Voltz M., Andrieux P. 1997. Diuron and simazine losses to runoff water in Mediterranean vineyards. Journal of Environmental Quality, 26, 1493-1502.

Letey J., Carrillo M.L.K., Pang X.P. 2000. Approaches to characterize the degree of water repellency. Journal of Hydrology, 231/232, 61-65.

Lewis S.A., Wu J.Q., Robichaud P.R. 2006. Assessing burn severity and comparing soil water repellency, Hayman Fire, Colorado. Hydrological Processes, 20, 1-16.

Lichner L., Babejová N., Dekker L.W. 2002. Effects of kaolinite and drying temperature on the persistence of soil water repellency induced by humic acids. Rostlinná výroba, 48 (5), 203-207.

Lozano E., Jiménez-Pinilla P., Mataix-Solera J., Arcenegui V., Bárcenas G.M., González-Pérez J.A., García-Orenes F., Torres M.P., Mataix-Beneyto J. 2013. Biological and chemical factors controlling the patchy distribution of soil water repellency among plant species in a Mediterranean semiarid forest. Geoderma, 207/208, 212-220.

Ma'shum M., Tate M.E., Jones G.P., Oades J.M. 1988. Extraction and characterization of water-repellent materials from Australian soils. Journal of Soil Science, 39, 99-110.

Mataix-Solera J., Arcenegui V., Guerrero C., Mayoral A.M., Morales J., González I., García-Orenes F., Gómez I. 2007. Water repellency under different species in a calcareous forest soil in a semiarid Mediterranean environment. Hydrological Processes, 58, 1254-1259. 
Mataix-Solera J., Arcenegui V., Tessler N., Zornoza R., Wittenberg L., Martínez C., Caselles P., Pérez-Bejarano A., Malkinson D., Jordán M.M. 2013. Soil properties as key factors controlling water repellency in fire-affected areas: Evidences from burned sites in Spain and Israel. Catena, 108, $6-13$.

Meeuwig R.O. 1971. Infiltration and water repellency in granitic soils. USDA Forest Service Research Paper, INT-111, 1-20.

Orzechowski M., Smólczyński S. Sowiński P., Rybińska B. 2013. Water repellency of soils with various content of organic mater in north-eastern Poland. Soil Science Annual, 64 (2), 30-33.

Rodríguez-Alleres M., Varela M.E., Benito E. 2012. Natural severity of water repellency in pine forest soils from NW Spain and influence of wildfire severity on its persistence. Geoderma, 191, 125-131.

Roper M.M. 2005. Managing soils to enhance the potential for bioremediation of water repellency. Australian Journal of Soil Research, 43, 803-810.

Shakesby R.A., Doerr S.H., Walsh R.P.D. 2000. The erosional impact of soil hydrophobicity: current problems and future research directions. Journal of Hydrology, 231/232, 178-191.

Societas Pedologica Slovaca 2000. Morphogenetic Soil Classification System of Slovakia. Basal Reference Taxonomy. Soil Science and Conservation Research Institute, Bratislava.

Szatyłowicz J., Oleszczuk R., Gnatowski T., Mączyńska E. 2006. Ocena zwilżalności utworów torfowych i murszowych na podstawie pomiarów kąta zwilżania pomiędzy fazą stałą gleby a wodą. In:
Właściwości fizyczne i chemiczne gleb organicznych (eds.: T. Brandyk, L. Szajdak, J. Szatyłowicz). Wyd. SGGW, Warszawa, 85-94.

Šimkovic I., Dlapa P., Šimonovičová A., Ziegler W. 2009. Water repellency of mountain forest soils in relation to impact of the katabatic windstorm and subsequent management practices. Polish Journal of Environmental Studies, 18 (3), 443-454.

Thorsen M.K., Hopkins D., McKenzie B. 2010. Sources and characteristics of water repellency in machair soil. Poster. University of Aberdeen and Scottish Crop Research Institute.

Wahl N.A. 2008. Variability of water repellency in sandy forest soils under broadleaves and conifers in north-western Jutland/Denmark. Soil and Water Research, 3 (1), 155-164.

Walkley A., Black I.A. 1934. An examination of the Degtjareff method for determining soil O.M. and a proposed modification of the chromic acid titration method. Soil Science, 37, 29-38.

Wang Z., Wu Q.J., Wu L., Ritsema C.J., Dekker L.W., Feyen J. 2000. Effects of soil water repellency on infiltration rate and flow instability. Journal of $\mathrm{Hy}$ drology, 231/232, 265-276.

Wylie L., Allinson G., Stagnitti F. 2001. Guidelines for the standardisation of the water drop penetration time test. $26^{\text {th }}$ General Assembly of the European Geophysical Society, EGS Nice France, 26-30 March 2001, Abstracts 3, 631-633.

Zavala L.M., Cerdà A., Alanís N. 2015. Soil water repellency: current knowledge and future insights. European Geosciences Union, General Assembly 2015, 12-17 April 2015, Vienna, Austria. 